\title{
Carbohydrate Reserves of Crested Wheatgrass and Russian Wildrye as Influenced by Development and Defoliation ${ }^{1}$
}

\author{
M. J. TRLICA, JR. AND C. WAYNE COOK \\ Research Assistant and Research Professor,2 Utah State University, I.ogan, Utah.
}

\section{Highlight}

Carbohydrate reserves of crested wheatgrass (Agropyron cristatum) and Russian wildrye (Elymus junceus) were lowest after initial spring growth, but maximum levels were rapidly attained as plants approached maturity. Fall regrowth caused reductions in total available carbohydrate (TAC) stores. More TAC reserves were used to produce new growth if plants were defoliated during spring growth than if defoliated at maturity or quiescence. Autumn TAC storage levels in both crested wheatgrass and Russian wildrye were reduced by all previous defoliations. Autumn reserve storage was directly related to the amount of new growth produced after defoliation. Results indicate that both crested wheatgrass and Russian wildrye are adapted for either fall or early spring grazing and under some circumstances for spring-fall use. Defoliation when plants are rapidly replenishing reserves or before maturity reduces subsequent new growth and carbohydrate reserve stores in the autumn.

Two introduced grasses, crested wheatgrass (Agropyron cristatum) and Russian wildrye (Elymus junceus) are important seeded rangeland species of the western United States and Canada. These two species are presently being utilized for grazing, erosion control and roadside revegetation. Information about (1) seeding methods (Cook, 1958; Cook, 1966; Cook et al., 1967; Cook et al., 1970), (2) growth responses after grazing or foliage removal (Cook and Stoddart, 1953; Cook et al., 1958; Frischknecht, 1968; Currie and Smith, 1970), (3) nutritive values (Cook and Harris, 1952; Cook and Harris, 1968), and (4) competitive relationships with other species (Cook and Lewis, 1963; Cook, 1965; Drawe, 1971) are available for these two species. Little information is available, however, on the physiological effects of defoliation for crested wheatgrass and Russian wildrye. This study was therefore conducted

1 This was a cooperative project between Utah State University and the Bureau of Land Management. Utah Agriculture Experiment Station journal paper 1221. Received November 20, 1971.

2 Now Assistant Professor and Head, Department of Range Science, Cola rado State University, respectively. from 1967 to 1969 to determine carbohydrate reserve stores for these two grasses as influenced by phcnological development and several defoliation treatments.

\section{Experimental Area and Procedure}

The study areas were located in central and northwestern Utah. The climate is semiarid with warm, dry summers and cold winters. Average yearly precipitation was slightly greater than the 10-year average of $28 \mathrm{~cm}$ during 1967 and 1968, and slightly less than average in 1969 . The spring and early summer of 1968 were dry, but about three times the normal amount of precipitation fell in August. Precipitation was below average throughout most of 1969. Site descriptions of these foothill ranges were given by Frischknecht (1968) and Drawe et al. (1972).

Both crested wheatgrass and Russian wildrye were seeded in the autumn of 1958 and 1960 following sagebrush (Artemisia tridentata) removal and summer fallow treatments. Plots containing both species were fenced to eliminate livestock grazing. Pure stands of each species on adjacent similar sites were selected for study.

Defoliation treatments of both species were made by clipping $90 \%$ of the plant's current photosynthetic tissue. Defoliations were made during early fall (September) of 1967 and 1968 when plants were mature. These were single defoliations in both cases. Because of late summer rains, both grasses had produced two new leaves per tiller before defoliation. The second single defoliation treatment for plants of both species was made after "killing" frosts in November of 1967 and 1968 when the plants were quiescent. Green leaf and stem bases were still present, however. Another single defoliation treatment was made during early growth (April) of 1968 and 1969 when both grasses had produced about $20 \%$ of their anticipated annual growth based on weight. Both species were in the second or third leaf stage of growth. A fourth single defoliation treatment was applied during early June of 1968 and 1969. Both grasses were at anthesis and had produced about $75 \%$ of their anticipated annual growth at this time. In all cases, different plants were defoliated each year. Data were therefore available for 2 years for each of the 4 single clipping treatments at 4 phenological stages of development.

In addition to the 4 single defoliation treatments, a fifth treatment was carried out by defoliating plants during quiescence (November) of one year and subsequently harvesting the same plants again in early growth (April) the following year in both 1967 and 1968 . A sixth treatment involved defoliating plants at anthesis (June) in 1968 and clipping the same plants again in September at maturity. Bccausc of dry conditions in 1969, little regrowth was made by plants clipped in late spring during anthesis; therefore, these plants were not clipped twice as in 1968.

In all cases, total available carbohydrates (TAC) from root and crown samples of defoliated plants were determined when plants had produced new growth equal to ap- 
proximately $20 \%$ of mature size. These determinations were compared with TAC concentrations of unclipped plants to determine the carbohydrate stores used for respiration and production of new growth. Root and crown samples from all defoliation treatments and control plants of crested wheatgrass and Russian wildrye also were collected during the autumn of each year for TAC analysis. Plants that had been defoliated during quiescence in 1967 and 1968 were not sampled until the following autumn of 1968 and 1969, respectively. Thus, a range of 2 months to a full year may have elapsed between various defoliation treatments and autumn sample collections. Unclipped plants of both species were sampled periodically throughout the autumn of 1967 and the growing season of 1968 to determine carbohydrate reserve fluctuations in roots and crowns throughout the annual growth cycle.

A separate experiment was conducted in the late summer and fall of 1967 and 1968 to determine the influence of additional soil water on plant regrowth and TAC storage. Both crested wheatgrass and Russian wildrye plants were clipped at maturity in early September and small earthen dikes were constructed at the base of the treated plants. Equal numbers of control plants of both species were selected in the same proximity and dikes were constructed around their bases. These plants were irrigated to provide additional soil water throughout the remainder of the growing season. Sixteen to 32 liters of water (equal to approximately $10 \mathrm{~cm}$ of precipitation) were supplied at 1 to 2-week intervals to each diked plant in an effort to stimulate fall regrowth. These plants were excavated in the fall, along with those plants not receiving additional water, to determine if soil water regime had a significant effect upon herbage regrowth and carbohydrate reserve storage.

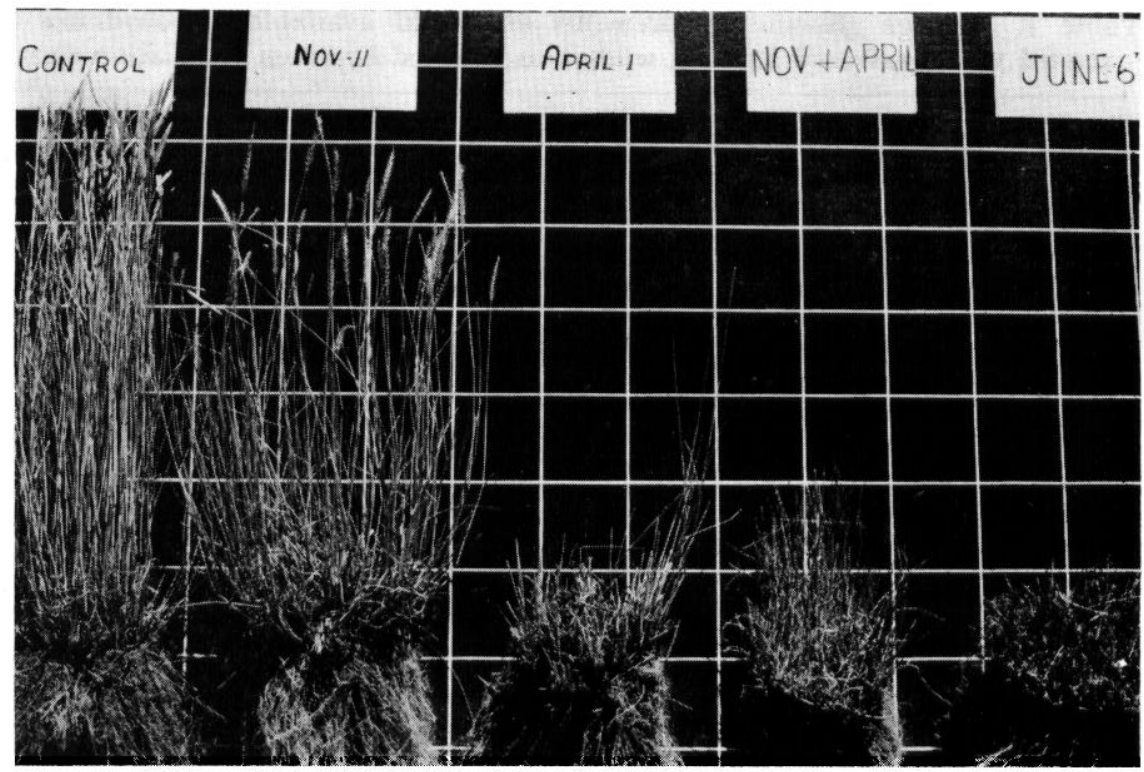

FIG. 1. Crested wheatgrass plants in the autumn from control, quiescence (Nov. 11), early growth (April 1), both quiescence and early growth (November and April) and anthesis (June 6) defoliation treatments.

Roots were separated from crowns in the field and washed with water. Grass root systems were collected to a $30 \mathrm{~cm}$ depth. The lower 4 to $5 \mathrm{~cm}$ of the culms, rhizomes, and tillers were designated as crown tissue. No attempt was made to separate live tissue from dead unless decay was obvious. These samples were placed in pint jars and covered with $95 \%$ ethanol to reduce enzyme activity. Samples were taken to the laboratory, lids were removed from the jars, and the jars placed in a forced-draft dryer at 70 C. Approximately 1 week was required to evaporate the ethanol and an additional week to dry the samples.

After drying, the samples were ground to pass through a 40-mesh screen. Laboratory analyses were conducted to determine TAC as milligrams of available carbohydrates per gram of dry plant matter. Weinmann (1947) and Smith et al. (1964) defined TAC to include sugars, dextrins, starches, and fructosans. Structural carbohydrates such as pentosans, hemicellulose, and cellulose were not included in the TAC fraction. No allowance was made for water of hydrolysis from polysaccharides in the calculations (Grotelueschen and Smith, 1967).

Extraction of TAC from $0.5 \mathrm{~g}$ samples of plant material was accomplished by using $0.2 \mathrm{~N}$ sulfuric acid as described by Smith et al. (1964). These extracts were analyzed on a glucose equivalent basis by using an iodometric titration developed by Heinze and Murneck (1940) with modifications of reagents as suggested by the Association of Official Agricultural Chemists (1965). Standard curves were determined for each stock solution.

\section{Results and Discussion}

Differences in growing conditions during the 3 years of this study caused yearly differences in growth of crested wheatgrass and Russian wildrye. Precipitation during 1968 was above normal and plant growth was greater. Plants clipped later in their yearly growth cycle produced less new growth by fall (Fig. 1). Both species followed similar trends in production of new growth following defoliations. Plants clipped at quiescence (November) or during early growth (April) produced more new growth by the following autumn than 
Table 1. Average growth measurements and total available carbohydrates (TAC) in the autumn of two years for crested wheatgrass and Russian wildrye as affected by seven defoliation treatments.

\begin{tabular}{|c|c|c|c|c|c|c|c|c|c|c|c|}
\hline \multirow{3}{*}{$\begin{array}{l}\text { Phenological } \\
\text { stage of } \\
\text { defollation }\end{array}$} & \multicolumn{5}{|c|}{ Crested wheatgrass } & \multicolumn{5}{|c|}{ Russian wildrye } & \multirow{3}{*}{$\begin{array}{l}\text { Average } \\
\text { TAC2 } \\
\text { (mg/g) }\end{array}$} \\
\hline & \multirow{2}{*}{$\begin{array}{l}\text { Curzent year's } \\
\text { growth } \\
\text { (cm) }\end{array}$} & \multirow{2}{*}{$\begin{array}{l}\text { Seedstal } \\
\text { length }\}^{k} \\
\text { (cm) }\end{array}$} & \multirow{2}{*}{$\begin{array}{l}\text { 7 growth attained } \\
\text { as compared with } \\
\text { contro1 }\end{array}$} & \multicolumn{2}{|c|}{$\begin{array}{l}\mathrm{TAC}^{2} / \\
(\mathrm{mg} / \mathrm{g})\end{array}$} & \multirow{2}{*}{$\begin{array}{l}\text { Current year's } \\
\text { growth } \\
\text { (cm) }\end{array}$} & \multirow{2}{*}{$\begin{array}{l}\text { Seedstalk } \\
\text { length } 1 / \text { f } \\
(\mathrm{cm})\end{array}$} & \multirow{2}{*}{$\begin{array}{l}\text { Z growth attained } \\
\text { as compared with } \\
\text { control }\end{array}$} & \multicolumn{2}{|c|}{$\begin{array}{r}\mathrm{TAC} 2 / \\
(\mathrm{mg} / \mathrm{g})\end{array}$} & \\
\hline & & & & Roots & Crowns & & & & Roots & Crowns & \\
\hline Control & 32 & 50 & 100 & $128 a$ & 113 & 30 & 75 & 100 & 137a & $84 n$ & 116 \\
\hline Quiescence & 26 & 48 & 73 & $115 \mathrm{ab}$ & $96 a$ & 28 & 58 & 83 & $112 b c$ & $75 a b$ & $100 a$ \\
\hline Early growth & 26 & 44 & 66 & $108 \mathrm{~b}$ & $89 a b$ & 26 & 55 & 75 & $124 \mathrm{ab}$ & $78 \mathrm{ab}$ & 100 e \\
\hline $\begin{array}{l}\text { Quiescence and } \\
\text { early growth }\end{array}$ & 23 & 42 & 54 & $118 \mathrm{ab}$ & $97 a$ & 23 & 58 & 74 & $115 b c$ & $77 a b$ & $102 a$ \\
\hline Anthesis & 8 & 0 & 20 & 83 & $78 \mathrm{~b}$ & 19 & 0 & 30 & $113 b c$ & $65 b$ & $85 \mathrm{~b}$ \\
\hline Maturity & 3 & 0 & 10 & $102 b$ & $79 b$ & 4 & 0 & 15 & $100 c$ & $78 \mathrm{ab}$ & $90 \mathrm{ab}$ \\
\hline $\begin{array}{l}\text { Anthesis and } \\
\text { maturity }\end{array}$ & 3 & 0 & 8 & 59 & 55 & 4 & 0 & 15 & $103 c$ & $66 \mathrm{~b}$ & $71 b$ \\
\hline
\end{tabular}

1/plants clipped at or after anthesis did not produce seedstalks.

2/ Treatment means in a column followed by a similar letter are not significantly different from each other at the .05 level of probability.

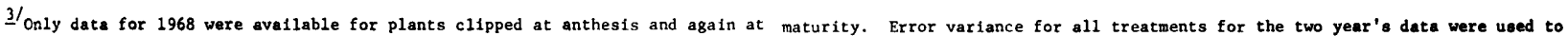

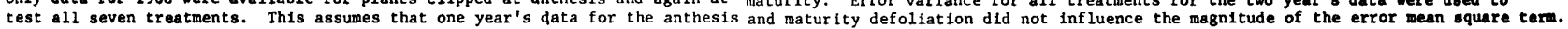

plants defoliated at anthesis (June) or at maturity (September). Plants defoliated at quiescence and again during early spring growth produced about as much new growth as plants clipped only once during early spring growth. When crested wheatgrass and Russian wildrye were clipped at anthesis and again at maturity, they produced about as much new growth by late autumn as when defoliated only once at maturity. Trends in seedstalk height after defoliation were similar to that of new growth production (Table 1).

Drawe et al. (1972) found Russian wildrye to be more productive than crested wheatgrass on similar sites under any intensity or season of defoliation. Clipping both species at light and moderate intensities during early or mid-spring growth was less detrimental to plant vigor than clipping after anthesis or clipping during early growth and again after anthesis. Similar trends in growth and production of these two grasses were found in the present study (Table I).

\section{Cycling of Carbohydrate Reserves}

Seasonal trends in carbohydrate reserve depletion during initial growth and the subsequent replenishment of reserves have been well documented for several range species (Sampson and McCarty, 1930;
Troughton, 1957; Weinmann, 1961; and Coyne and Cook, 1970). Hyder and Sneva (1959) described the growing season trends in total available carbohydrates of roots and stem bases of crested wheatgrass. However, the carbohydrate reserve cycles throughout a year for both crested wheatgrass and Russian wildrye growing on similar sites have not been compared.

Total available carbohydrates (TAC) in roots and crowns of crested wheatgrass and Russian wildrye followed somewhat similar patterns (Fig. 2 and 3). Carbohydrate reserves were high in the fall and decreased to a low level during initial spring growth. The lowest TAC level was found during early growth (April) when approximately $20 \%$ growth had been produced by both species. Approximately 50 to $60 \%$ of the reserves stored the previous summer and fall were used in respiration and initial growth the following spring. Crested wheatgrass and Russian wildrye were at the second to third leaf stage during the period of low reserve concentrations. Thereafter carbohydrate reserves in both roots and crowns rapidly accumulated until maxi-

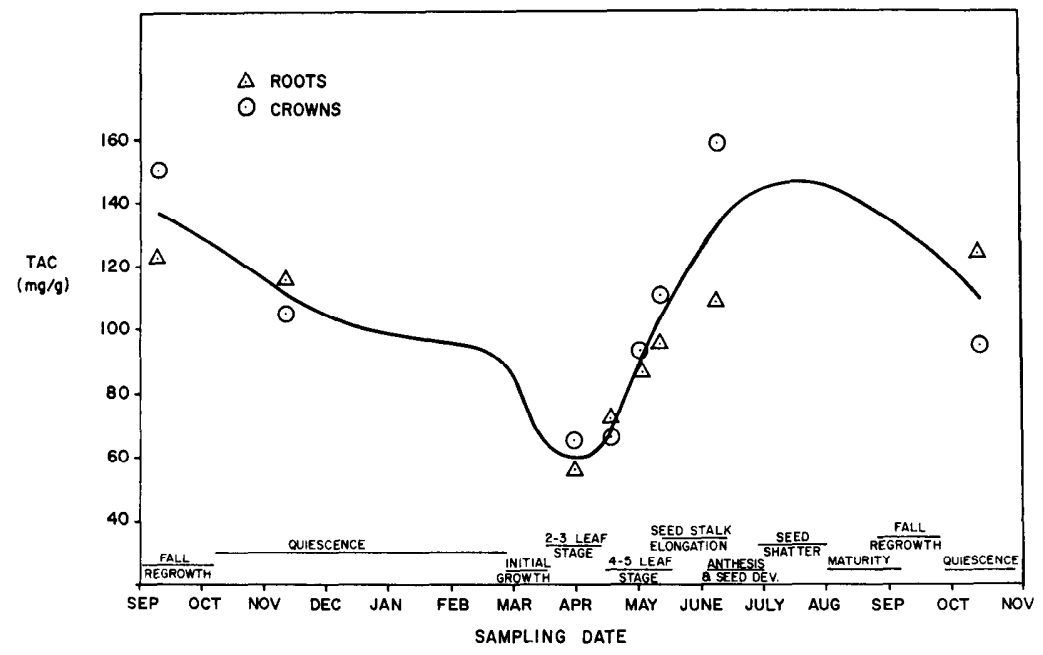

FIG. 2. Total available carbohydrates (TAC) in roots and crowns of crested wheatgrass (1967-1968) as related to stage of phenological development. Theoretical TAC cycle is indicated by the line in this graph. 


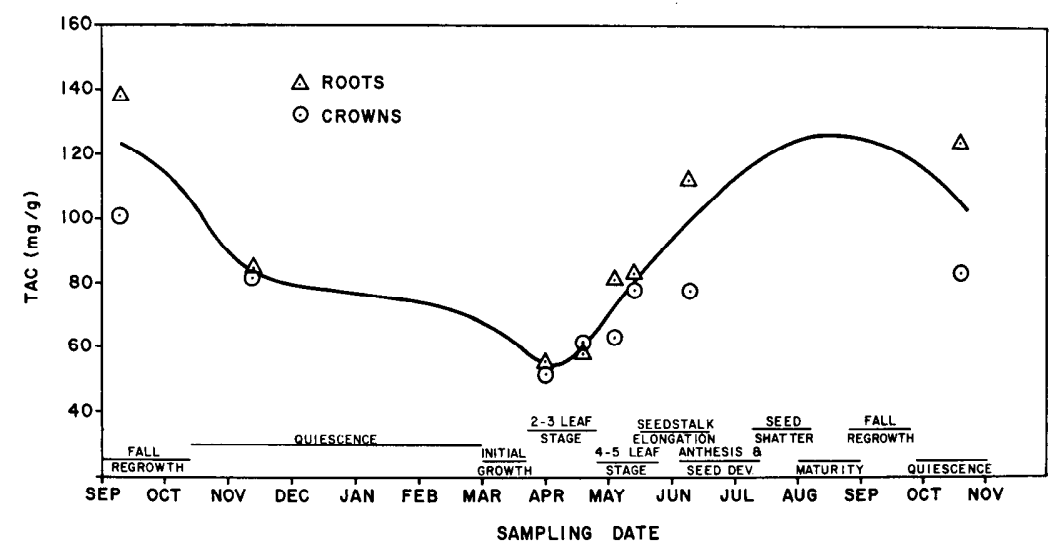

Fig. 3. Total available carbohydrates (TAC) in roots and crowns of Russian wildrye (1967-1968) as related to stage of phenological development. Theoretical TAC cycle is indicated by the line in this graph.

mum levels were attained as plants neared maturity (Fig. 2 and 3 ).

The decline of reserve levels in crowns of crested wheatgrass and roots of Russian wildrye in the fall of 1967 may be attributed largely to fall regrowth (Fig. 2 and 3 ). Russian wildrye produced about 5 to $10 \%$ more regrowth than crested wheatgrass, which may account for greater reductions in autumn TAC storage levels in Russian wildrye.

The growing season trend in TAC concentrations for both species was similar to that reported for crested wheatgrass by Hyder and Sneva (1959). They attributed the rapid increase of reserve storage levels after initial growth to abundant leafiness and a delay in stem elongation. This was probably true for both crested wheatgrass and Russian wildrye in the present study. Since both grasses had similar phenological development, both had similar reserve depletion and restoration patterns. Reserve replenishment during vegetative growth was more rapid however for crested wheatgrass than for Russian wildrye (Fig. 2 and 3).

Both root and crown storage concentrations of crested wheatgrass and Russian wildrye followed somewhat similar trends. Root reserves were, however, greater $(\mathrm{p}<.01)$ than crown reserve concentrations at fall quiescence (Fig. 2 and 3). Trlica and Cook (1971) found au- tumn crown reserve concentrations to be greater than root reserve concentrations for Indian ricegrass (Oryzopsis hymenoides) and needleandthread (Stipa comata).

Effects of Additional Water on Regrowth and Carbohydrate Storage

Additional soil water that was supplied during the late summer and fall of 1967 and 1968 to control plants and plants that had been defoliated at maturity caused both crested wheatgrass and Russian wildrye to resume growth. Watered plants produced an average of one more leaf per tiller and 10 to $20 \%$ more regrowth than did unwatered plants. This additional growth caused a significant reduction $(p<.05)$ in autumn TAC storage levels of both species. The TAC level in roots and crowns of plants that received additional water were about $15 \%$ lower than reserve levels in unwatered plants.

A significant interaction $(\mathrm{p}<$ .05) between plant parts and years was probably caused by greater increases in root TAC storage than crown storage in 1968. More favorable growing conditions during 1968 may have caused greater root storage levels at quiescence during that year.

Carbohydrate Reserve Stores as Affected by Defoliation Treatments

Both crested wheatgrass and Russian wildrye used similar amounts of TAC to produce $20 \%$ new growth after defoliation. No differential utilization of reserves from roots or crowns was observed. However, significant differences $(p<.05)$ were found in the amount of TAC utilized among plants from various defoliation trcatments to produce $20 \%$ new growth. Both grasses used more reserves to produce $20 \%$ new growth when clipped during early growth than when clipped at maturity or quiescence. Higher temperatures and respiration rates during the late spring and summer regrowth period may have contributed to greater reductions in TAC reserves for plants defoliated during early growth.

The amount of new growth produced by defoliated plants was directly related to the time remaining in the growing season (Fig. I). As would be expected, plants defoliated the previous autumn at quiescence or during early spring growth produced more new growth than plants clipped at anthesis or maturity. Differences in growing conditions during the 3 years caused significant differences $(p<.05)$ in length of current year's growth and seedstalk lengths among years; however, significant differences in autumn reserve levels among years were not present.

Autumn carbohydrate reserves were similar for crested wheatgrass and Russian wildrye. Comparable phenological development and responses to growing conditions may account for the similarity in fall reserve stores of these two grasses.

Clipping significantly reduced fall reserve levels of both grasses as comparcd to unclipped plants (Table 1). However, only small reductions in autumn TAC storage occurred when plants were defoliated during quiescence the previous year or during early growth the same year. Trlica and Cook (1971) earlier reported similar results for desert range species. Crested wheatgrass and Russian wildrye plants that were clipped at either anthesis or maturity, or 
clipped at anthesis and again at maturity, had substantial reductions in TAC stores in the autumn (Table 1). Plants from these 3 treatments had little chance for regrowth before autumn frosts and consequently had little photosynthetic tissue for carbon dioxide assimilation and carbohydrate storage during the normal storage period. Thaine (1954) reported that carbohydrate reserves of Russian wildrye diminished with increased clipping frequency during the growing season. The present study indicated however, that clipping crested wheatgrass or Russian wildryc at quicscence and again during early growth was no more detrimental to TAC storage than clipping them once at the later stage of phenological development.

Root TAC reserves were reduced more by defoliations than were crown reserves (Table 1). A highly significant interaction $(p<.01)$ between root and crown TAC levels and species was caused by larger differences between TAC levels of roots and crowns of Russian wildrye as compared with roots and crowns of crested wheatgrass. The roots of Russian wildrye from any defoliation treatment were considerably higher in TAC than the crowns.

Although autumn carbohydrate reserves were directly related to the amount of photosynthetic tissue present during normal storage periods, regression analysis indicated that variability in TAC levels (Y's) could not be accounted for by differences in percentage of new growth attained compared to controls, length of current year's growth, and seedstalk heights (X's). Measurements of these independent variables could only account for as much as $34 \%$ of the variability in autumn TAC stores of crested wheatgrass and Russian wildrye. If other measures of plant vigor at quiescence were utilized, such as leaf area, weight, and crown cover, then plant carbohydrate reserve status might be predicted with greater accuracy. Mc-
Kendrick and Sharp (1970) found that herbage production of crested wheatgrass was highly correlated with organic reserve index, basal area per plant, and number of tillers per unit surface area.

Results from this study suggest that both crested wheatgrass and Russian wildrye are physiologically adapted for fall or early spring grazing and possibly for spring-fall grazing as suggested by Hyder and Sneva (1963). Grazing when plants are rapidly replenishing reserves during late spring or before fall quiescence however, may cause serious reductions in plant TAC reserves and new growth. Carbohydrate reserve data support the findings of Drawe et al. (1972) that clipping during the latter part of the growing season or combined early and late spring clipping arc detrimental to vigor of crested wheatgrass and Russian wildrye.

\section{Summary and Conclusions}

A study was conducted from 1967 to 1969 in central and northwestern Utah to determine seasonal carbohydrate reserve cycles and how various defoliation treatments affected utilization and storage of carbohydrate reserve in crested wheatgrass and Russian wildrye. Phenological development and autumn carbohydrate levels were similar for both grasses. Root and crown reserve levels were lowest after initial spring growth; however, reserves were rapidly accumulated and maximum levels were attained as plants approached maturity.

Fall regrowth stimulated either by natural rainfall or irrigation caused reductions in total available carbohydrates (TAC) stores during this period. Irrigated plants produced 10 to $20 \%$ more regrowth and reserve levels were about $15 \%$ lower than plants which did not receive additional water. Carbohydrate reserves of plants which produced fall regrowth were not replenished before fall quiescence.

Both crested wheatgrass and Russian wildrye used similar amounts of TAC to produce new growth following defoliation. More reserves were utilized to produce $20 \%$ new growth if plants were defoliated during early growth than if defoliated during maturity or quiescence.

Autumn reserve levels in both crested wheatgrass and Russian wildrye were reduced if plants had been defoliated as compared to unclipped plants. Plants defoliated at either anthesis or maturity had less autumn TAC stores than plants defoliated at quiescence the previous fall or during early spring growth. Defoliations at quiescence and again during early growth were usually no more detrimental to TAC storage in these grasses than a single defoliation, when the single defoliation was carried out at the later phenological stage of development. Autumn reserve stores were directly related to the amount of new growth produced after being defoliated. However, percentage new growth attained compared to controls, length of current year's growth, and seedstalk heights could only account for $34 \%$ of the variation in autumn TAC storage levels.

Results from this study indicate that both crested wheatgrass and Russian wildrye are physiologically adapted for fall or early spring grazing and possibly for spring-fall range. However, grazing when plants are rapidly replenishing reserves or before fall quiescence may be detrimental to plant welfare.

\section{Literature Cited}

Association of Official Agricultural Chemists. 1965. Official methods of analysis of the Association of Official Agricultural Chemists. 10th Ed. Washington, D.C. p. 498-499.

Соок, C. W. 1958. Sagebrush eradication and broadcast seeding. Utah Agr. Exp. Sta. Bull. 404. 23 p.

Cook, C. W. 1965. Grass seedling response to halogeton competition. J. Range Manage. 18:317-321.

Соок, C. W. 1966. Development and use of foothill ranges in Utah. Utah Agr. Exp. Sta. Bull. 461.47 p.

Cook, C. W., and L. E. Harris. 1952. 
The nutritive value of cheatgrass and crested wheatgrass on spring ranges of Utah. J. Range Manage. 5:331-337.

Cook, C. W., and L. E. Harris. 1968. Nutritive value of seasonal ranges. Utah Agr. Exp. Sta. Bull. 472 . 55 p. Cook, C. W., AND C. E. Lewis. 1963. Competition between big sagebrush and seeded grasses on foothill ranges in Utah. J. Range Manage. 16:245250.

Cook, C. W., and L. A. Stoddart. 1953. Some growth responses of crested wheatgrass following herbage removal. J. Range Manage. 6: 267-270.

Cook, C. W., L. A. Stoddart, and F. E. Kinsinger. 1958. Response of crested wheatgrass to various clipping treatments. Ecol. Monogr. 28: 237-272.

Cook, C. W., L. A. Stoddart, and P. L. Sims. 1967. Effects of season, spacing, and intensity of seeding on the development of foothill range grass stands. Utah Agr. Exp. Sta. Bull. $467.73 \mathrm{p}$.

Cook, C. W., I. B. Jensen, G. B. Coltharp, AND E. M. Larsen. 1970. Seeding methods for Utah roadsides. Utah Resources Series 52. 23 p.

Coyne, P. I., AND C. W. Cook. 1970. Seasonal carbohydrate reserve cycles in eight desert range species. J. Range Manage. 23:438-444.

Currie, P. O., ANd D. R. Smith. 1970.
Response of seeded ranges to different grazing intensities. U.S. Dep. Agr., Production Res. Rep. No. 112. $41 \mathrm{p}$.

DraWE, D. L. 1971. An evaluation of factors affecting establishment and survival of Russian wildrye (Elymus junceus Fisch.) on foothill ranges in Utah. Unpub. Ph.D. Diss. Utah State Univ., Logan. 117 p.

Drawe, D. L., J. B. Grumbles, and J. F. HOOPER. 1972. Clipping effects on seeded foothill ranges in Utah. J. Range Manage. 25:426-429.

FrISCHKNECHT, N. C. 1968. Grazing intensities and systems on crested wheatgrass in central Utah: Response of vegetation and cattle. U.S. Dep. Agr., Tech. Bull. 1388. 47 p. Grotelueschen, R. D., AND D. Smith. 1967. Determination and identification of nonstructural carbohydrates removed from grass and leg. ume tissue by various sulfuric acid concentrations, takadiastase and water. Agr. and Food Chem. 15: 1048-1051.

Heinze, P. H., and A. E. Murnfek. 1940. Comparative accuracy and efficiency in determination of carbohydratcs in plant material. Mo. Agr. Exp. Sta. Res. Bull. 314. 23 p.

Hyder, D. N., ANd F. A. Sneva. 1959. Growth and carbohydrate trends in crested wheatgrass. J. Range Manage. 12:271-276.

Hyder, D. N., ANd F. A. SNeva. 1963.
Morphological and physiological factors affecting the grazing management of crested wheatgrass. Crop Sci. 3:267-271.

McKendrick, J. D., And L. A. Sharp. 1970. Relationship of organic rcserves to herbage production in crested wheatgrass. J. Range Manage. 23:434-438.

Sampson, A. W., and E. C. McCarty. 1930. The carbohydrate metabolism of Stipa pulchra. Hilgardia 5:61100.

Smith, D., G. M. Paulsen, and C. A. RAGUSE. 1964. Extraction of total available carbohydrates from grass and legume tissue. Plant Physiol. 39:960-962.

Thaine, R. 1954. The effect of clipping frequency on the productivity and root development of Russian wildrye grass in the field. Can. J. Agr. Sci. 34:299-304.

Troughton, A. 1957. The underground organs of herbage grasses. Commonwealth Bur. Pastures and Field Crops Bull. 44. 163 p.

Trlica, M. J., Jr., and C. W. Cook. 1971. Defoliation effects on carbohydrate reserves of desert species. J. Range Manage. 24:418-425.

WeinmanN, H. 1947. Determination of total available carbohydrates in plants. Plant Physiol. 22:279-290.

Weinmann, H. 1961. Total available carbohydrates in grasses and legumes. Herbage Abstr. 31:255-261. 